\title{
Investigation of ruminant encephalitic and septicemic listeriosis by the immunofluorescence method
}

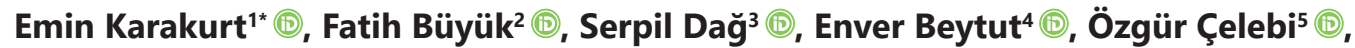

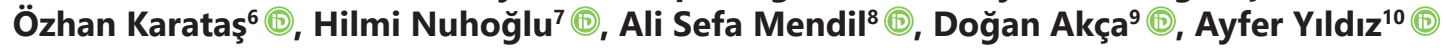 \\ 1,3,4,7,10 Kafkas University, Veterinary Faculty, Pathology Department, Kars, Turkey \\ ${ }^{2,5}$ Kafkas University, Veterinary Faculty, Microbiology Department, Kars, Turkey \\ ${ }^{6}$ Cumhuriyet University, Veterinary Faculty, Pathology Department, Kars, Turkey \\ ${ }^{8}$ Erciyes University, Institute Health Sciences, Kayseri, Turkey \\ ${ }^{9}$ Kafkas University, Health Science Faculty, Midwifery Department, Kars, Turkey
}

Geliş Tarihi / Received: 05.06.2020, Kabul Tarihi / Accepted: 20.04.2021

\begin{abstract}
Listeria genus is Gram-positive facultative intracellular bacteria that are found in the soil as saprophytes but also contain species that have pathogenic effects in their last host. Listeria monocytogenes is the major pathogen in Listeria species that is responsible for the majority of Listeriosis cases in humans and animals. In this study, it was aimed to investigate L. monocytogenes with histopathological and immunofluorescence (IF) methods in brain and liver tissues taken from sheep and cattle with clinical signs of suspicious Listeriosis. In the study, isolation and identification of $L$. monocytogenes with cultural methods were also applied. The material of the study consisted of tissue samples from 16 sheep and 2 cattle. As a result of cultural analysis, L. monocytogenes was identified from $12(66.6 \%)$ of cases. Within the framework of histopathological and macroscopic findings, 16 (88.8\%) of 18 cases with suspected Listeriosis were positive with the immunofluorescence method. These findings reveal that the immunofluorescent staining method is a reliable and sensitive method in the diagnosis of Listeriosis.
\end{abstract}

Keywords: Cattle, immunofluorescence, listeriosis, sheep

\section{Ruminantların ensefalitik ve septisemik listeriyozisinin immunfloresan metodla araştırılması}

\begin{abstract}
Özet: Listeria cinsi toprakta saprofit olarak bulunan ancak aynı zamanda son konaklarında patojenik etkilere sahip türler içeren Gram-pozitif fakültatif intraselüler bakterilerdir. Listeria monocytogenes, insanlarda ve hayvanlarda Listeriosis vakalarının çoğundan sorumlu olan Listeria türlerindeki başlıca patojendir. Bu çalışmada, Listeriyozis şüpheli klinik belirti gösteren koyun ve sığırlardan alınan beyin ve karaciğer dokularında L. monocytogenes'in histopatolojik ve immunfloresan metodlarla araştırılması amaçlanmıştır. Çalışmada L. monocytogenes'in kültürel yöntemlerle izolasyonu ve identifikasyonu da uygulanmıştır. Çalışmanın materyalini, 16 koyun ve iki sığıra ait doku örnekleri oluşturmuştur. Kültürel analiz sonucunda vakaların $12(\% 66,6)$ 'sinden L. monocytogenes identifiye edilmiştir. Histopatolojik ve makroskobik bulgular çerçevesinde Listeriyozis şüpheli 18 vakanın 16 (\%88,8)'sı immunfloresan metodla pozitif tespit edilmiştir. Bu bulgular, immunfloresan boyama yönteminin Listeriyozisin teşhisinde güvenilir ve hassas bir yöntem olduğunu ortaya koymaktadır.
\end{abstract}

Anahtar kelimeler: İmmunfloresan, koyun, listeriyozis, sığır

\section{Introduction}

Listeria spp. are saprophytic, Gram-positive bacteria that are distributed widely in the environment (Nightingale et al. 2004; Fairley et al. 2012; Rocha et al. 2013). The genus Listeria consists of the currently known species $L$. monocytogenes, L. ivanovii, $L$. seeligeri, L. innocua, L. grayi, and L. welshimeri (Liu et al. 2004). Only two of these six species are known to be pathogenic: L. monocytogenes and L. ivanovii (Oevermann et al. 2010). Especially, L. monocytogenes is responsible for about $98 \%$ of human and $85 \%$ of animal cases of listeriosis (Kaur et al. 2010). Listeriosis is a sporadic, infrequently seen as an enzootic disease of ruminants. This disease causes significant economic losses in sheep, cattle, and goats. (Dag et al. 2013). Listeriosis is mostly detected in autumn, winter, and early spring in temperate and cold climates and there is a direct link between poorly prepared silage feeding and infection (Wesley et al. 2002; Brugère-Picoux 2008). This disease is more common in sheep than in cattle (Çeribaşı et al. 2013). The most important clinical symptoms caused by $L$. monocytogenes in ruminants are briefly as follows: septicemia, meningoencephalitis,

Yazışma adresi / Correspondence: Emin Karakurt, Kafkas University, Veterinary Faculty, Pathology Department, Kars, Turkey E-posta: mehmeteminkarakurt@hotmail.com

ORCID IDs of the authors: ${ }^{10000-0003-2019-3690 ~} \cdot{ }^{2} 0000-0003-3278-4834 \cdot{ }^{3} 0000-0001-7667-689 X \cdot$ ${ }^{4} 0000-0003-3360-2940 \cdot{ }^{5} 0000-0002-3478-008 X \cdot{ }^{6} 0000-0002-2778-8059 \cdot{ }^{7} 0000-0003-2530-2542 \cdot{ }^{8} 0000-0003-2722-3290 \cdot$ $90000-0002-3986-8769 \cdot{ }^{10} 0000-0002-6569-5435$ 
metritis with abortion (Barkallah et al. 2016; Haligur et al. 2019). In encephalitic form; multifocal microabscesses, meningoencephalitis, glial nodules, perivascular cuffing are the main histopathological features (Özyıldız et al. 2018). Multiple necroses and numerous abscess foci in the liver are seen in septicemic listeriosis (Low and Donachie 1997). Moreover, L. monocytogenes is an important foodborne pathogen for humans and poses a major problem on public health (Dreyer et al. 2015). Human cases are mostly associated with the ingestion of contaminated milk and/or milk products (Headley et al. 2014).

Definitive diagnosis of listeriosis is based on the isolation and identification of the agent by bacteriological culture techniques. Some alternatives may helpful in diagnosis to detect Listeria spp. or erupted antibodies with PCR and serological techniques, respectively (Gasanov et al. 2005). However, all these techniques have some drawbacks such as requiring equipped laboratory environment and personnel and time-consuming and labour-intensive efforts, as well. Thus, a simple and reliable technique is always needed in the diagnosis of Listeria agents. Immunological methods using monoclonal or polyclonal antibodies have been demonstrated to give promising results for rapid detection of $L$. monocytogenes in various samples (Ralovich 1993). These antibodies labeled with the fluorescent compound can identify the target antigens on smears prepared from tissues when examined with a fluorescence microscope which is called a direct immunofluorescence assay (Chen et al. 2017).

In this study, it was aimed to evaluate the samples of brain and liver tissue from sheep and cattle with encephalitic and septicemic listeriosis associated with Listeria monocytogenes by histopathological and immunofluorescence methods.

\section{Material and Methods}

\section{Animals}

Study materials were obtained from adult 16 sheep and 2 cattle admitted to The Pathology Department and Microbiology Department of Veterinary Faculty, Kafkas University, for necropsy. These animals had various clinical symptoms, including anorexia, depression, unable to stand up, hypersalivation, sagging in the lower lip, paralysis in the eyelid, abortion, circling movement, opisthotonus, loss of coordination, unilateral blindness, amaurosis, and torticollis.

\section{Microbiological Analysis}

In this study, brain and liver tissues of all animals and also kidney and heart samples from one sheep (Case No.7) were cultivated in accordance with the USDA-FSIS method reported by McClain and Lee (1988) with some minor modifications. In brief $2.5 \mathrm{~g}$ tissue was transferred to $22.5 \mathrm{ml}$ PreEnrichment Broth (Trypticase Soy Broth (Merck 1.05459 ) containing $0.6 \%$ yeast extract and the broth was incubated microaerobically at $30{ }^{\circ} \mathrm{C}$ for 24 hours. At the end of the incubation, $1 \mathrm{ml}$ Preenrichment Broth was transferred into $9 \mathrm{ml}$ Listeria Enrichment Broth (UVM formulation) (Oxoid $\mathrm{CM0863)}$, and the latter was incubated at $30^{\circ} \mathrm{C}$ at the same conditions. Then, Listeria Selective Agar (LSA) (Oxoid, CM0856) was plated with $25 \mu \mathrm{l}$ aliquot of Listeria Enrichment Broth and the plates were incubated microaerobically for 24 hours at $30^{\circ} \mathrm{C}$. Initial identification was performed with the presence of bright grey-black centered smooth colonies on the LSA medium which was considered as Listeria spp. Future identification was performed through Gram staining characteristics, mobility at $25^{\circ} \mathrm{C}$, catalase and oxidase activities, carbohydrate (L-rhamnose, D-mannitol, D-xylose, and $\alpha$-methylmannosidase) fermentation capabilities, and CAMP activities with control strains of Rhodococcus equi (ATCC-33701) and Staphylococcus aureus (ATCC25923) (FDA, 2015).

\section{Histopathological examination}

Tissue samples of brain and liver from 16 sheep and two cattle and in addition to these, kidney and heart samples from only one sheep (Case No.7) were fixed in a $10 \%$ neutral buffered formalin solution. After routine tissue procedures follow-up, $5 \mu \mathrm{m}$ thick sections were taken from paraffin blocks. In order to detect histopathological changes, Hematoxylin \& Eosin (H\&E) stain was applied to the sections. Sections were examined under a light microscope (Olympus Bx53) and photographed with Cell $\wedge P$ Program (Olympus Soft Imaging Solutions $\mathrm{GmbH}$, $3,4)$.

\section{Immunofluorescence staining}

Direct immunofluorescence staining protocol was carried out to detect L. monocytogenes antigens on tissue sections. Briefly, liver, brain, negative and positive tissues from cattle and sheep were fixed in a $10 \%$ neutral buffered formalin solution. Tissues were routinely followed by alcohol-xylol followup and taken into paraffin blocks. Sections of 5 $\mu \mathrm{m}$ taken into poly-L-lysine sections were passed 
through xylol and alcohol series. Sections were treated with antigen retrieval solution at 500 watts for $2 \times 5$ minutes to reveal the antigen in the tissues. The tissues washed with PBS were then incubated for 10 minutes in 1\% Bovine Serum Albumin (BSA) and then incubated with L. monocytogenes (LSBio Catalog no: LS-C56360) primary antibody for 45 minutes at $37^{\circ} \mathrm{C}$. Then, it was washed with distilled water and the sections were covered with 46 , 6-diamidino-2-phenylindole (DAPI) fluorescence medium. Results obtained under fluorescence microscope were evaluated as negative $(-)$, mild $(+)$, moderate $(++)$, and severe $(+++)$.

\section{Results}

\section{Microbiological Results}

In this study, Listeria spp. were isolated from 12 (66.6\%) animals, one cattle, and 11 sheep (Table
1). The isolates had some characteristics such as the presence of colonies with certain morphology on LSA, typical microscopic morphologies (0.4$0.5 \mu \mathrm{m}$ wide and 1-2 $\mu \mathrm{m}$ long, non-spore-forming Gram-positive bacilli), catalase-positive and oxidase negative activities and motility at $25^{\circ} \mathrm{C}$. All isolates were further identified as $L$. monocytogenes as the result of L-rhamnose and $\alpha$-methyl-mannosidase activities and positive CAMP reaction with $S$. aureus.

\section{Macroscopical results}

In addition to marked congestion in the brain, it was detected an increase in opacity and thickening in meninges (Figure 1A). In the liver, white foci of pin size spread across the entire organ were observed (Figure 1B). It was detected nodular structures in the heart in only one case (Figure 1C). It did not observe any macroscopic findings in kidney tissue (Figure 1D).

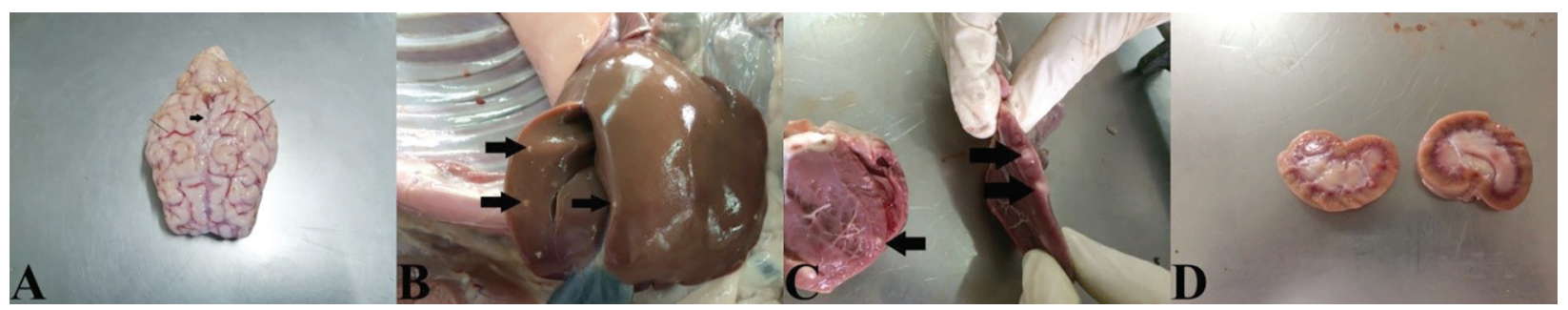

Figure 1. A: Brain, congestion (thin arrows) and meningeal opacity and thickening (thick arrow), B: Liver, white foci of pin size spread across the entire organ (arrows), C: Heart, nodular structures (arrows), D: Kidney, there was no macroscopically significant finding (granulomatous case).

\section{Microscopical results}

The findings observed in the histopathological examination of brain tissues were briefly as follows: extensive coagulative necrosis areas and intense neutrophil infiltrations around these areas (Figure 2A), meningitis (Figure 2B), microabscesses (Figure 2C), perivascular cuffs consisting mainly of lymphocytes with histiocytes, plasma cells and a small number of neutrophils (Figure 2C), gliosis (Figure 2D) (Table 1).
In addition to these findings observed in the brain, it was detected areas of necrosis in the liver (Figure $3 \mathrm{~A}$ ), perivascular cell infiltrations (Figure 3A-B), numerous abscess foci (Figure 3C), granulomatous structure (Figure 3D), giant cell (Figure 3D), degeneration in hepatocytes (Figure 3D), hemorrhage and proliferation in the bile ducts. It was detected granulomatous structures in the kidney and heart in only one case (Figure 4A-B) (Table 1).

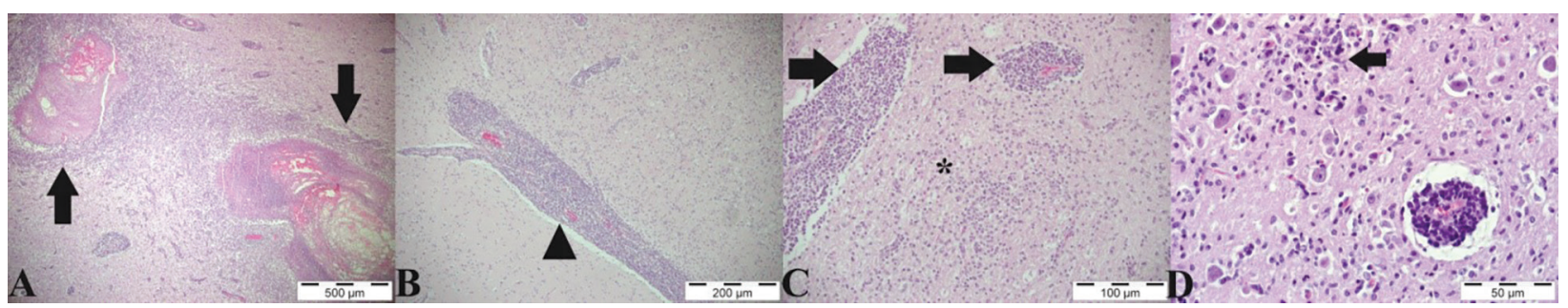

Figure 2. A: Brainstem, Extensive coagulative necrosis areas and intense neutrophil infiltrations around these areas (arrows), H\&E, Bar=500 $\mu \mathrm{m}$ B: Brainstem, Meningitis (arrowhead), H\&E, Bar=200 $\mu \mathrm{m}$ C: Brainstem, Perivascular cuffing (arrows) and microabscess (star), H\&E, Bar=100 $\mu \mathrm{m}$ D: Brainstem, Gliosis, H\&E, Bar=50 $\mu \mathrm{m}$. 


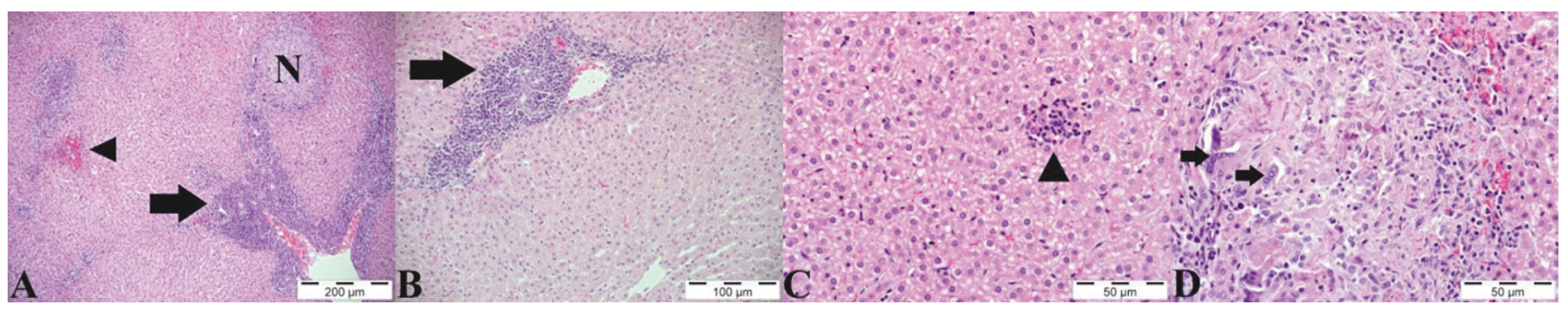

Figure 3. A: Liver, Necrosis ( $N$ ), perivascular cellular infiltration (arrow) and hemorrhage (arrowhead), $\mathrm{H} \& \mathrm{E}, \mathrm{Bar}=200 \mu \mathrm{m}$ B: Liver, perivascular cellular infiltration (arrow), $\mathrm{H} \& \mathrm{E}, \mathrm{Bar}=100 \mu \mathrm{m}$ C: Liver, degenerate hepatocytes and microabscess (arrowhead), $\mathrm{H} \& \mathrm{E}, \mathrm{Bar}=50 \mu \mathrm{m}$ D: Liver, granuloma, giant cells (arrows), $\mathrm{H} \& \mathrm{E}$, Bar $=50 \mu \mathrm{m}$.

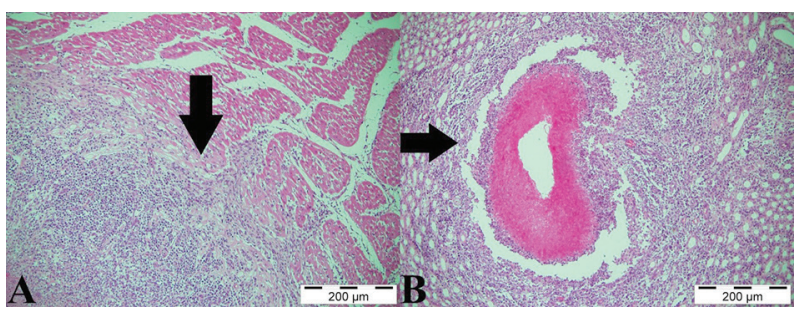

Figure 4. A: Heart, granuloma, $H \& E, B a r=200 \mu m$ B: Kidney, granuloma, $\mathrm{H} \& \mathrm{E}, \mathrm{Bar}=200 \mu \mathrm{m}$.

\section{Immunofluorescence staining results}

As the result of IF staining, 16 (88.8\%) of 18 cases with suspected Listeriosis were positive (Table 1). In the sections used for control purposes, we observed nonspecific fluorescence luminescence only in erythrocytes. In IF evaluations, it was detected L. monocytogenes antigens diffusely located in the cytoplasm of hepatocytes (Figure 5A-B). In the brain, it was observed that the antigens were diffuse in the cytoplasm of neurons, similar to that in liver findings (Figure 6A-D).
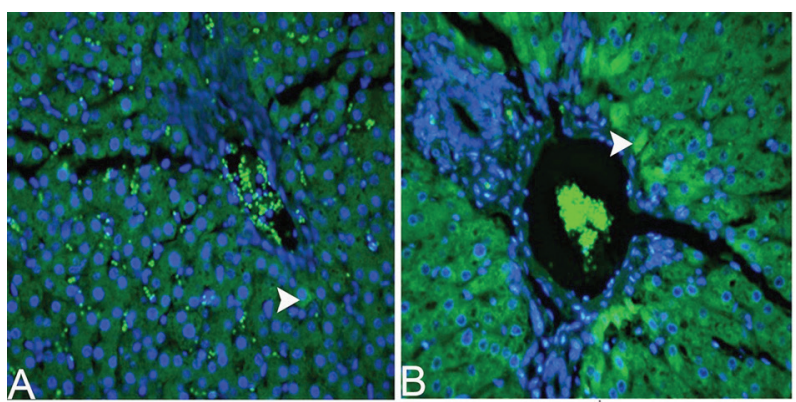

Figure 5. A-B: Listeria monocytogenes positivity in the cytoplasm of hepatocytes (arrowhead). Liver, IF method, 20x.
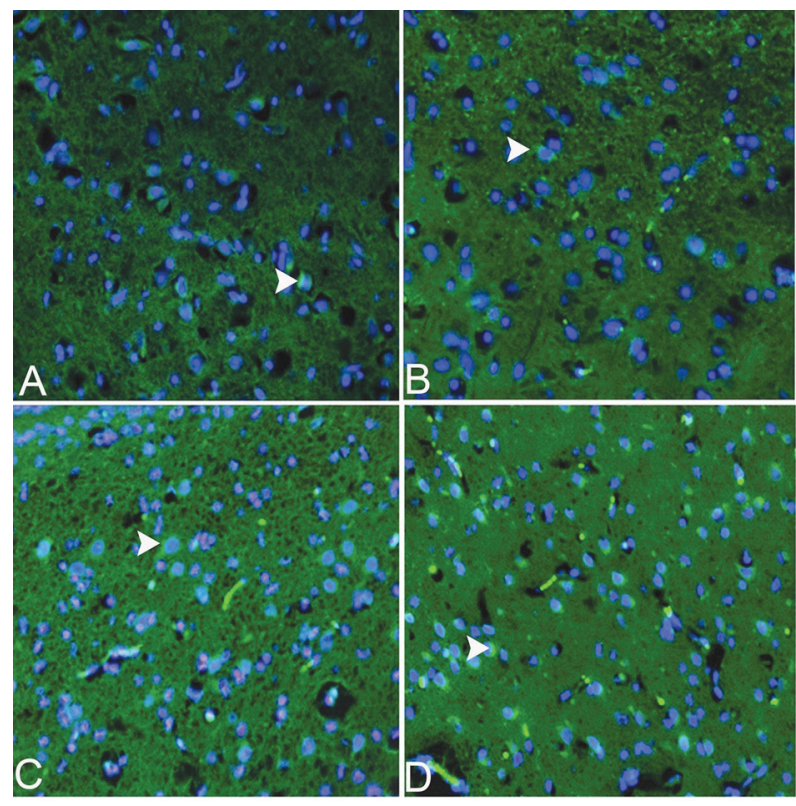

Figure 6. A-B-C-D: Listeria monocytogenes positivity in the cytoplasm of neurons (arrowhead), Brain, IF method, 20x.

\section{Discussion}

Listeriosis, caused primarily by L. monocytogenes, is a common infectious disease reported in countries on over six continents and in more than 40 species of domesticated and wild animals. However, this disease is an important health problem especially for ruminants (Langohr et al. 2006). Encephalitic listeriosis is observed most in sheep among ruminants (Campero et al. 2002). In our study, in accordance with the literature data (Campero et al. 2002), listeriosis positive cases were mostly detected in sheep. Generally, Listeriosis is detected more often in winter and early spring and is thought to be related to poorly prepared silage consumption (Al-Dughaym et al. 2001; Wesley et al. 2002). The 
animals included in our study consisted mostly of sheep brought to our department, especially in winter, similar to the literature data (Al-Dughaym et al. 2001; Campero et al. 2002; Wesley et al. 2002). Listeriosis can be evaluated pathologically under three main headings. The first of these; infection of the pregnant uterus and late-term abortions, the second is septicemia characterized by milier visceral abscesses (liver, spleen, and other organs) and the third is encephalitis (Ortatatlı et al. 2001; Nightingale et al. 2004; Headley et al. 2014). The clinical manifestations of Listeriosis are a result of the lesions in the brain stem and although individual cases vary, common symptoms include apathy, fever, anorexia, depression, abortion, septicemia, conjunctivitis, nystagmus, facial and tongue paralysis, dullness, turning or twisting of the head to one side and walking in circles (Low and Donachie 1997; Dons et al. 2007; Brugère-Picoux 2008; Çeribaşı et al. 2013). Death occurs 2-3 days after the clinical symptoms are observed in sheep. This period is longer in cattle (Low and Donachie 1997). In the animals of our study, consistent with the literature (Low and Donachie 1997; Ortatatlı et al. 2001; Brugère-Picoux 2008; Çeribaşı et al. 2013), clinical symptoms such as anorexia, depression, unable to stand up, hypersalivation, sagging in the lower lip, paralysis in the eyelid, abortion, circling movement, opisthotonus, loss of coordination, unilateral blindness, amaurosis, and torticollis were observed.

Macroscopic lesions in listeriosis are generally not remarkable (Rocha et al. 2013). However, it is known that sometimes the membranes covering the medulla oblongata are thickened due to greenish gelatinous edema and there are a few $\mathrm{mm}$ diameter melting areas on the sectional face of the medulla oblongata. (Ortatatlı et al. 2001). Significant congestion and blurred meningeal edema have also been reported (Al-Dughaym et al. 2001; Headley et al. 2014; Haligur et al. 2019). Focal hepatic necrosis and white nodules are observed in the liver (Low and Donachie 1997). Pyogranulomas can be observed in lymph nodes, lungs, liver, spleen, and kidneys (Dreyer et al. 2015). In our study, similar to previous studies (Al-Dughaym et al. 2001; Headley et al. 2014; Haligur et al. 2019), we found an increase in opacity and thickening and significant congestion in meninges. We also detected white nodules spread over the entire organ surface in the liver, similar to that reported by Low and Donachie (1997). In just one case, in addition to macroscopic lesions in the liver and brain, we encountered nodular areas in the heart. Although macroscopic findings in the kidney are not remarkable, we observed granulomatous structures in the histopathological examination of this organ, as reported by Dreyer et al. (2015).

In previous studies, microabscesses (Oevermann et al. 2010; Rocha et al. 2013; Henke et al. 2015), foci of malacia infiltrated by neutrophils (Johnson et al. 1995; Al-Dughaym et al. 2001; Ortatatlı et al. 2001; Campero et al. 2002), meningoencephalitis (ilhan et al. 2012; Headley et al. 2014), perivascular cuffs consisting mainly of lymphocytes with histiocytes, plasma cells and infrequent neutrophils (Low and Donachie 1997; Çeribaşı et al. 2013; Özyıldız et al. 2018; Haligur et al. 2019), gliosis (Ligios et al. 2004; Loeb 2004; İlhan et al. 2012; Özyıldız et al. 2018), multiple foci of necrosis of the liver (Brugère-Picoux 2008) have been observed. Similar to the results of these researchers, we observed large areas of necrosis, microabscesses, meningoencephalitis, gliosis, and perivascular cuffing in the brain. In addition, we determined necrosis in the liver, numerous abscess foci, and perivascular cell infiltrations, in correlation with the findings of some researchers (Low and Donachie 1997; Brugère-Picoux 2008). We detected granulomatous structures in the kidney and heart in only one case similar to the literature data (Dreyer et al. 2015).

In the diagnosis of listeriosis, besides bacteriological culture techniques, immunohistochemical staining, electron microscopy, ELISA, and PCR methods are also used. However, all these techniques have some disadvantages. (Weinstock et al. 1995; Loeb 2004; Kaur et al. 2010; Dag et al 2013; Özyıldız et al. 2018). We couldn't find literature data in which the presence of $L$. monocytogenes in adult sheep and cattle was evaluated by immunofluorescence staining. There are few immunofluorescence studies evaluating the brain cells of cattle and embryonic rats (Dramsi et al. 1998; Henke et al. 2015).

In conclusion, based on histopathological and macroscopic findings, 16 of 18 cases in which we suspected Listeriosis were positively diagnosed by the immunofluorescence method. It was thought that the difference between culture results and immunofluorescence results is in favor of immunofluorescence due to specific binding. Within the scope of the results obtained from our study, we think that immunofluorescence staining is a very reliable and sensitive method in the diagnosis of Listeriosis. We believe that the results of immunofluorescence staining will contribute to the literature in terms of diagnosis of encephalitic and septicemic listeriosis in ruminants. 
Table 1. Comparison of the results of diagnostic tests for all animals.

\begin{tabular}{|c|c|c|c|c|c|c|}
\hline Case No & Species & Sample Type & $\begin{array}{l}\text { Histopathological } \\
\text { Results }\end{array}$ & $\begin{array}{c}\text { Microbiological } \\
\text { Results }\end{array}$ & $\begin{array}{c}\text { IF } \\
\text { Results }\end{array}$ & $\begin{array}{c}\text { Severity of IF } \\
\text { Expressions }\end{array}$ \\
\hline \multirow{2}{*}{1} & \multirow{2}{*}{ Cattle } & Liver & $\mathrm{N}$ & - & - & - \\
\hline & & Brain & ME & - & - & - \\
\hline \multirow{2}{*}{2} & \multirow{2}{*}{ Sheep } & Liver & $\mathrm{N}$ & - & + & ++ \\
\hline & & Brain & $\mathrm{ME}, \mathrm{MA}, \mathrm{N}, \mathrm{PC}, \mathrm{G}$ & - & + & ++ \\
\hline \multirow{2}{*}{3} & \multirow{2}{*}{ Sheep } & Liver & $\mathrm{N}, \mathrm{PCl}, \mathrm{A}$ & - & + & + \\
\hline & & Brain & $E$ & - & - & - \\
\hline \multirow{2}{*}{4} & \multirow{2}{*}{ Sheep } & Liver & $\mathrm{N}$ & - & - & - \\
\hline & & Brain & $\mathrm{ME}, \mathrm{MA}, \mathrm{N}, \mathrm{PC}, \mathrm{G}$ & - & + & ++ \\
\hline \multirow{2}{*}{5} & \multirow{2}{*}{ Sheep } & Liver & $\mathrm{N}$ & - & - & - \\
\hline & & Brain & $M E, P C$ & - & + & + \\
\hline \multirow{2}{*}{6} & \multirow{2}{*}{ Sheep } & Liver & $\mathrm{N}$ & - & - & - \\
\hline & & Brain & ME & - & - & - \\
\hline \multirow{4}{*}{7} & \multirow{4}{*}{ Sheep } & Liver & $\mathrm{N}$ & + & + & +++ \\
\hline & & Brain & ME & + & + & +++ \\
\hline & & Heart & GR & + & - & - \\
\hline & & Kidney & GR & + & - & - \\
\hline \multirow{2}{*}{8} & \multirow{2}{*}{ Sheep } & Liver & $\mathrm{N}, \mathrm{PCl}, \mathrm{A}$ & + & + & +++ \\
\hline & & Brain & $\mathrm{ME}, \mathrm{MA}, \mathrm{N}, \mathrm{PC}, \mathrm{G}$ & + & + & +++ \\
\hline \multirow{2}{*}{9} & \multirow{2}{*}{ Sheep } & Liver & $\mathrm{N}, \mathrm{PCl}, \mathrm{A}$ & + & + & +++ \\
\hline & & Brain & $\mathrm{ME}, \mathrm{MA}, \mathrm{N}, \mathrm{PC}, \mathrm{G}$ & + & + & +++ \\
\hline \multirow{2}{*}{10} & \multirow{2}{*}{ Sheep } & Liver & $\mathrm{N}, \mathrm{PCl}, \mathrm{A}$ & + & + & +++ \\
\hline & & Brain & $\mathrm{ME}, \mathrm{MA}, \mathrm{N}, \mathrm{PC}, \mathrm{G}$ & + & + & +++ \\
\hline \multirow{2}{*}{11} & \multirow{2}{*}{ Sheep } & Liver & $\mathrm{N}, \mathrm{PCI}$ & + & + & ++ \\
\hline & & Brain & $M E, M A, N, P C, G$ & + & + & ++ \\
\hline \multirow{2}{*}{12} & \multirow{2}{*}{ Sheep } & Liver & $\mathrm{N}$ & + & - & - \\
\hline & & Brain & $M E, P C$ & + & + & + \\
\hline \multirow{2}{*}{13} & \multirow{2}{*}{ Sheep } & Liver & $\mathrm{N}, \mathrm{PCl}, \mathrm{A}$ & + & + & ++ \\
\hline & & Brain & $\mathrm{ME}, \mathrm{MA}, \mathrm{N}, \mathrm{PC}, \mathrm{G}$ & + & + & ++ \\
\hline & & Liver & $\mathrm{N}, \mathrm{PCl}, \mathrm{A}$ & + & + & +++ \\
\hline 14 & Sheep & Brain & $\mathrm{ME}, \mathrm{MA}, \mathrm{N}, \mathrm{PC}, \mathrm{G}$ & + & + & +++ \\
\hline & & Liver & $\mathrm{N}, \mathrm{PCl}, \mathrm{A}$ & + & + & +++ \\
\hline 15 & Sheep & Brain & $\mathrm{ME}, \mathrm{MA}, \mathrm{N}, \mathrm{PC}, \mathrm{G}$ & + & + & +++ \\
\hline 16 & Cattle & Liver & $\mathrm{N}, \mathrm{PCI}$ & + & + & +++ \\
\hline 16 & Cattle & Brain & $M E, M A, N, P C, G$ & + & + & +++ \\
\hline & & Liver & $N$ & + & + & ++ \\
\hline 17 & Sheep & Brain & $\mathrm{ME}, \mathrm{MA}, \mathrm{N}, \mathrm{PC}, \mathrm{G}$ & + & + & ++ \\
\hline 18 & & Liver & N, PCl, A & + & + & +++ \\
\hline 18 & sheep & Brain & $\mathrm{ME}, \mathrm{MA}, \mathrm{N}, \mathrm{PC}, \mathrm{G}$ & + & + & +++ \\
\hline & & Number of Pos & ve Cases & 12 & 16 & \\
\hline
\end{tabular}

N: Necrosis, ME: Meningoencephalitis, MA: Microabscesses, PC: Perivascular cuffing, G: Gliosis, GR: Granuloma, PCl: Perivascular cell infiltrations, A: abscess

Ethic statement: The ethics committee report of this study was obtained from Kafkas University Animal Experiments Local Ethics Committee (Authorization number: KAU-HADYEK-2020/075).
Conflict of Interest Statement: The authors declare no conflicts of interest with respect to the publication of this manuscript. 


\section{References}

Al-Dughaym AM, Elmula AF, Mohamed GE, Hegazy AA, Radwan YA, Housawi FM, Gameel AA. (2001) First report of an outbreak of ovine septicaemic listeriosis in Saudi Arabia. Rev Sci Tech. 2001; 20, 777-783.

Barkallah M, Gharbi Y, Hmani M, Mallek Z, Gautier M, Gdoura R Fendri I. (2016) Locked nucleic acid probe-based real-time PCR for the diagnosis of Listeria monocytogenes in ruminants. Mol Cell Probes. 30, 138-145.

Brugère-Picoux J. (2008) Ovine listeriosis. Small Ruminant Res. 76, 12-20.

Campero CM, Odeón AC, Cipolla AL, Moore DP, Poso MA Odriozola E. (2002) Demonstration of Listeria monocytogenes by immunohistochemistry in formalin-fixed brain tissues from natural cases of ovine and bovine encephalitis. $J$ Vet Med B Infect Dis Vet Public Health. 49, 379-383.

Çeribaşı S, Kızıl Ö, Karahan M. (2013) Listeriyozisli koyunlarda klinik, patolojik ve mikrobiyolojik bulgular. F Ü Sağ Bil Vet Derg. 27, 1-5.

Chen JQ, Regan P, Laksanalamai P, Healey S, Hu Z. (2017) Prevalence and methodologies for detection, characterization and subtypingof Listeria monocytogenes and L. ivanovii in foods and environmental sources. FSHW. 6, 97-120.

Dag S, Akca D, Karaman D, Celebi O, Ozen H, Buyuk F, Sahin M. (2013) Investigation of immunoperoxidase technique in smears prepared from vaginal secretions in use of early diagnosis of listerial abortions in cattle. Kafkas Univ Vet Fak Derg. 19, 1-6.

Dons L, Jin Y, Kristensson K, Rottenberg ME. (2007) Axonal transport of Listeria monocytogenes and nerve-cell-induced bacterial killing. J Neurosci Res. 85, 2529-2537.

Dramsi S, Lévi S, Triller A, Cossart P. (1998) Entry of Listeria monocytogenes into neurons occurs by cell-to-cell spread: an in vitro study. Infect Immun. 66, 4461-4468.

Dreyer $M$, Thomann A, Böttcher S, Frey J, Oevermann A. (2015) Outbreak investigation identifies a single Listeria monocytogenes strain in sheep with different clinical manifestations, soil and water. Vet Microbiol. 179, 69-75.

Fairley RA, Pesavento PA, Clark RG. (2012) Listeria monocytogenes infection of the alimentary tract (enteric listeriosis) of sheep in New Zealand. J Comp Pathol. 146, 308-313.

Food and Drug Administration (FDA). (2015) Testing methodology for Listeria species or $L$. monocytogenes in environmental samples. Version 1, Pp.2-11.

Gasanov U, Hughes D, Hansbro PM. (2005) Methods for the isolation and identification of Listeria spp. and Listeria monocytogenes: A review. FEMS Microbiol Rev. 29, 851-875.

Haligur M, Aydogan A, Ozmen O, Ipek V. (2019) Immunohistochemical evaluation of natural cases of encephalitic listeriosis in sheep. Biotech Histochem. 94, 341347.

Headley SA, Bodnar L, Fritzen JT, Bronkhorst DE, Alfieri AF, Okano W, Alfieri AA. (2014) Histopathological and molecular characterization of encephalitic listeriosis in small ruminants from northern Paraná, Brazil. Braz J Microbiol. 44, 889-896.

Henke D, Rupp S, Gaschen V, Stoffel MH, Frey J, Vandevelde M, Oevermann A. (2015) Listeria monocytogenes spreads within the brain by actin-based intra-axonal migration. Infect Immun. 83, 2409-2419.

İlhan F, Ulusoy Y, Halıgür M. (2012) Matrix metalloproteinase expression in sheep with listerial meningoencephalitis. Res Vet Sci. 92, 269-272.
Johnson GC, Fales WH, Maddox CW, Ramos-Vara JA. (1995) Evaluation of laboratory tests for confirming the diagnosis of encephalitic listeriosis in ruminants. J Vet Diagn Invest. 7, 223-228.

Kaur S, Malik SV, Bhilegaonkar KN, Vaidya VM, Barbuddhe SB. (2010) Use of a phospholipase-C assay, in vivo pathogenicity assays and PCR in assessing the virulence of Listeria spp. Vet J. 184, 366-370.

Langohr IM, Ramos-Vara JA, Wu CC, Froderman SF. (2006) Listeric meningoencephalomyelitis in a cougar (Felis concolor): Characterization by histopathologic, immunohistochemical, and molecular methods. Vet Pathol. 43, 381-383.

Ligios C, Viglietti A, Carta P, Dexter G, Agrimi U, Simmons MM. (2004) Clinicopathological findings in sheep from Sardinia showing neurological signs of disease. Vet Rec. 154, 365-370.

Liu D, Ainsworth AJ, Austin FW, Lawrence ML. (2004) PCR detection of a putative $\mathrm{N}$-acetylmuramidase gene from Listeria ivanovii facilitates its rapid identification. Vet Microbiol. 101, 83-89.

Loeb E. (2004) Encephalitic listeriosis in ruminants: Immunohistochemistry as a diagnostic tool. J Vet Med A Physiol Pathol Clin Med. 51, 453-455.

Low JC, Donachie W. (1997) A review of Listeria monocytogenes and listeriosis. Vet J. 153, 9-29.

McClain D, Lee WH. (1988) Development of USDA-FSIS method for isolation of Listeria monocytogenes from raw meat and poultry. J Assoc Off Anal Chem. 71, 660-664.

Nightingale KK, Schukken $\mathrm{YH}$, Nightingale CR, Fortes ED, Ho AJ, Her Z, Grohn YT, McDonough PL, Wiedmann M. (2004) Ecology and transmission of Listeria monocytogenes infecting ruminants and in the farm environment. Appl Environ Microbiol. 70, 4458-4467.

Oevermann A, Di Palma S, Doherr MG, Abril C, Zurbriggen A, Vandevelde M. (2010) Neuropathogenesis of naturally occurring encephalitis caused by Listeria monocytogenes in ruminants. Brain Pathol. 20, 378-390.

Ortatatı I M, Çiftçi MK, Tuzcu M. (2001) Bir koyun sürüsünde görülen purulent ensefalitis. Vet Bil Derg. 17, 97-102.

Özyıldız Z, Dinçel GÇ, Terzi OS, Özsoy ŞY, Kul O. (2018) Immunohistochemical investigation of the damage to and repair of myelin, and astrocyte activity in small ruminants resulting from with natural meningoencephalitic listeriosis. Ankara Üniv Vet Fak Derg. 65, 283-290.

Ralovich B. (1993) Detection and epidemiological typing of Listeria strains - diagnostic methods for Listeria infections (A review). Acta Microbiol Hung. 40, 3-38.

Rocha PR, Lomonaco S, Bottero MT, Dalmasso A, Dondo A, Grattarola C, Zuccon F, Iulini B, Knabel SJ, Capucchio MT, Casalone C. (2013) Ruminant rhombencephalitis-associated Listeria monocytogenes strains constitute a genetically homogeneous group related to human outbreak strains. Appl Environ Microbiol. 79, 3059-3066.

Weinstock D, Horton SB, Rowland PH. (1995) Rapid diagnosis of Listeria monocytogenes by immunohistochemistry in formalin-fixed brain tissue. Vet Pathol. 32, 193-195.

Wesley IV, Larson DJ, Harmon KM, Luchansky JB, Schwartz AR. (2002) A case report of sporadic ovine listerial menigoencephalitis in lowa with an overview of livestock and human cases. J Vet Diagn Invest. 14, 314-321. 